\title{
OUVIDOS ATENTOS: AS VOZES PLURAIS DE ITAMAR ASSUMPÇÃO
}

\author{
Attentive ears: the plural voices of Itamar Assumpção
}

\section{Bruno César Ribeiro Barbosa}

\author{
https://orcid.org/0000-0001-9351-2707 \\ Instituto Federal de Educação, Ciência e Tecnologia de Alagoas, Marechal Deodoro, AL, \\ Brasil.57160-000 - gabinete.marechal@ifal.edu.br
}

\begin{abstract}
Resumo: Este trabalho apresenta uma leitura da canção "Prezadíssimos ouvintes", de Itamar Assumpção e Domingos Pellegrini, gravada originalmente em 1985, no disco Sampa midnight - isso não vai ficar assim, de Itamar Assumpção - um dos nomes mais representativos da "Vanguarda Paulista" - cena musical bastante irreverente e criativa, que despontou inicialmente nos limites do pequeno teatro Lira Paulistana - também um selo de música independente, no qual Itamar Assumpção gravou seu primeiro LP, o Beleléu leléu eu, em 1981. O objetivo deste estudo é mostrar que, entre as diferentes estratégias utilizadas por Itamar ao longo de sua carreira, está um modelo composicional que privilegia a multiplicidade de vozes e de gêneros, estabelecendo, assim, diálogos com sua memória cultural e/ou afetiva, como veremos na canção abordada. A análise tem como base, sobretudo, as noções de voz e oralidade, de Paul Zumthor (2010); de "vozes plurais", de Adriana Cavarero (2011); e canção e entoação, de Luiz Tatit (2002).
\end{abstract}

Palavras-chave: Itamar Assumpção. Canção. Poesia. Vozes. Performance.

Abstract: This work presents a reading of the song "Prezadíssimos ouvintes", by Itamar Assumpção and Domingos Pellegrini, originally recorded in 1985, on the record Sampa midnight - isso não vai ficar assim, by Itamar Assumpção - one of the most representative names of "Vanguarda Paulista" - very irreverent and creative music scene, which initially emerged at the limits of the small theater Lira Paulistana - also an independent music label, on which Itamar Assumpção recorded his first LP, Beleléu leléu eu, in 1981. The purpose of this study is to show that, among the different strategies used by Itamar throughout his career, there is a compositional model that privileges the multiplicity of voices and genres, thus establishing dialogues with his cultural and / or affective memory, as we will see in the song addressed. The analysis is based, above all, on the notions of voice and orality, by Paul Zumthor (2010); "plural voices", by Adriana Cavarero (2011); and song and intonation, by Luiz Tatit (2002).

Keywords: Itamar Assumpção. Song. Poetry. Voices. Performance.

\section{Introdução}

Com oito discos lançados, incluindo duas trilogias e um álbum póstumo ${ }^{1}$, o paulista de

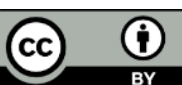

Esta obra está licenciada sob uma Creative Commons - Atribuição 4.0

\footnotetext{
${ }^{1}$ As trilogias Bicho de 7 cabeças, de 1993; e Pretobrás, cujo primeiro disco foi lançado em 1998, enquanto os outros dois foram lançados postumamente, em 2010. O outro álbum lançado um ano após a sua morte, em 2004, foi gravado em parceria com o músico Naná Vasconcelos, o Vasconcelos e Assumpção - Isso vai dar repercussão.
}

Anu. Lit., Florianópolis, v. 25, n. 2, p. 86-100, 2020. ISSNe 2175-7917 
Tietê, filho de Januário Assumpção e Maria Aparecida Silva de Assumpção, desenvolveu uma poética que envolve diferentes estratégias: do experimentalismo vocal, com a constante participação de cantoras e cantores inventivos e talentosos, às regravações de Ataulfo Alves e à parceria com o percursionista Naná Vasconcelos. Seus discos, editados às expensas do compositor $^{2}$, receberam nomes provocativos, como Beleléu, leléu, eu (1981), Às próprias custas S/A (1982) e Sampa Midnight - Isso não vai ficar assim (1985), entre outros.

Em Beleléu (1989), por exemplo, na faixa de abertura do disco³ ${ }^{3}$ Itamar Assumpção já nos oferece uma importante pista a respeito de como encarava o processo criativo e a execução de seu trabalho, e, mais ainda, de como provavelmente gostaria que se desse a recepção de sua obra por parte do público ouvinte. Como num programa de rádio, a voz de um locutor (interpretada pelo próprio Itamar) se dirige diretamente ao público, dizendo-lhe, em tom de exigência: "ouvidos atentos". Logo em seguida, apresenta o personagem marginalizado que dá nome ao disco e seu "perigosíssimo bando", destacando o nome dos músicos integrantes da banda (ou do "bando") que o acompanha, antes que eles tivessem tocado quaisquer instrumentos, antes, portanto, da execução das faixas. A relação entre artista e marginal é destacada, assim, de modo irônico por Itamar, mas pode ser lida também dentro de um contexto em que essa ironia indica a precariedade de condições de sobrevivência do artista, na sociedade brasileira, em especial do artista negro que vem de famílias de baixa renda, como é o caso de Assumpção.

Nesse contexto, sua poética, desde seus primeiros discos, já apontava para a criação de um modelo composicional bastante peculiar, em que a multiplicidade - de gêneros musicais, de performance e de vozes - é elemento-chave em suas canções. Logo nas primeiras composições, já se observam algumas marcas desse modelo composicional. Desde a diversidade de gêneros musicais, quanto a de vozes, citações e referências.

Dessa forma, é fundamental para este trabalho a noção de "vozes plurais", expressão livremente inspirada nas leituras de Adriana Cavarero, em seu Vozes plurais: filosofia da expressão vocal, de 2011 (tradução de Flavio Terrigno Barbeitas). A autora, professora de Filosofia Política na Universidade de Verona e estudiosa do pensamento feminista e de Hannah Arendt, direciona, no referido livro, suas reflexões para, entre outras coisas, a corporeidade da voz - algo de que a filosofia teria se ocupado pouco ao longo de sua história, segundo sua perspectiva. Logo de início, Cavarero (2011), após abordar as reflexões de Paul Zumthor sobre o tema, destacando que este também questiona o fato de não haver, entre as disciplinas institucionais, nenhuma ciência da voz, escreve:

[...] o âmbito da voz é constitutivamente mais amplo que o da palavra: ele o excede. Reduzir este excedente a insensatez - isto é, ao que resta quando a voz não está intencionada a um sentido que se quer domínio exclusivo da

\footnotetext{
${ }^{2}$ Com exceção do Intercontinental! Quem diria! Era só o que faltava!!!, gravado e lançado pela gravadora Continental, em 1988.

3 "Vinheta radiofônica". O detalhe é que nas edições mais recentes, essa vinheta de apresentação foi transferida para a penúltima faixa do disco, antes de "Nego Dito", perdendo, com isso, esse caráter irônico de apresentar os músicos antes que os mesmos tivessem tocado quaisquer instrumentos, como havia no original.
}

Anu. Lit., Florianópolis, v. 25, n. 2, p. 86-100, 2020. ISSNe 2175-7917 
palavra - é um dos vícios capitais do logocentrismo. Esse vício transforma o excedente em falta. (CAVARERO, 2011, p. 28).

E essa falta, como negação de sentido autônomo da voz, independentemente da linguagem, acaba propiciando um desafio, que, para Cavarero (2011), é o objetivo primordial de suas discussões: o de "pensar a relação entre voz e palavra como uma relação de unicidade" (2011, p. 29), afinal, novamente segundo a autora, “o próprio da voz não está no puro som; está mais na unicidade relacional de uma emissão fônica que, longe de contradizê-lo, anuncia e leva a seu destino o fato especificamente humano da palavra" (2011, p. 30).

Percebe-se, portanto, que Cavarero (2011) chama a atenção para o fato de que a voz carrega consigo o corpo de seu emissor e o anuncia, articulando, assim, de modo indissolúvel, corpo e palavra. Além disso, e mais adiante no mesmo livro, a autora destaca outro ponto importante referente à unicidade da voz. Ela aponta que, no contexto da crítica literária, a

'voz' é hoje um termo técnico que indica a peculiaridade do estilo de um poeta ou, mais genericamente, de um autor. Esse uso é interessante principalmente por remeter a uma unicidade vocálica que permanece subtendida e que, ao mesmo tempo, é alterada e deslocada de seu registro sonoro: o fato de que não existem duas vozes humanas absolutamente idênticas faz com que, na literatura, 'voz' se torne equivalente geral de diferença expressiva [...] (CAVARERO, 2011, p. 113).

Desse modo, seguindo essa linha de raciocínio defendida por Cavarero (2011), e relacionando-a às discussões propostas neste trabalho, a voz de Itamar Assumpção - ou, no sentido metafórico indicado acima, o seu estilo de compor e de cantar, conforme veremos mais adiante - não só o apresenta ao público, como corpo e voz literalmente, como também apresenta a esse mesmo público um modelo composicional marcado pela pluralidade de vozes, como indicador de seu estilo, justamente por não haver "duas vozes absolutamente idênticas", como dito acima. E ainda que esse sentido de voz como "equivalente geral de diferença expressiva" possa também nos ajudar a entender as especificidades da produção poética de Itamar Assumpção, não será este o foco da análise, pois Itamar assume, já desde seus primeiros discos, que sua voz (ou seu estilo) é, na verdade, uma grande colcha de retalhos, uma soma constante das múltiplas vozes que dialogam com a sua o tempo todo; tanto no eco das vozes das cantoras que o acompanham quanto nas ressonâncias advindas de sua memória enquanto ouvinte, leitor e compositor, afinal, e em harmonia com o pensamento do poeta, ensaísta e tradutor mexicano Octavio Paz, em Os filhos do barro (2013, p. 162), “o poeta não é 'autor' no sentido tradicional da palavra, mas um momento de convergência das diferentes vozes que confluem no texto." Assim, a "voz" de Itamar Assumpção, ou sua "diferença expressiva" em relação a outros compositores brasileiros, está certamente muito mais ligada à forma como o compositor arranja, em suas composições, todas essas vozes e referências; como ele, de fato, costura essa diversificada colcha de retalhos.

No entanto, por mais que esta seja considerada a sua marca, sua diferença expressiva, não pretendo, aqui, realizar exaustivos e hierárquicos comparativos entre poetas e cantores, nem 
tampouco apontar na obra de Itamar Assumpção procedimentos composicionais que sejam absolutamente originais e exclusivos. $\mathrm{O}$ autor, assim como suas canções, é também uma construção, o que nos remete novamente ao conceito de "vozes plurais" que defendemos neste artigo.

Essa multiplicidade de vozes, como elemento distintivo da produção musical e poética de Itamar Assumpção, sobretudo por seu caráter performático, nos faz lembrar das importantes considerações sobre os temas "poesia oral" e "performance", do teórico suíço Paul Zumthor (2010), para quem, a voz

[...] constitui um acontecimento do mundo sonoro, do mesmo modo que todo movimento corporal o é do mundo visual e táctil. Entretanto, ela escapa, de algum modo, da plena captação sensorial: no mundo da matéria, apresenta uma espécie de misteriosa incongruência. Por isso, ela informa sobre a pessoa, por meio do corpo que a produziu: mais do que por seu olhar, pela expressão do seu rosto, uma pessoa é traída por sua voz [...]. A enunciação da palavra ganha em si mesma valor de ato simbólico: graças à voz ela é exibição e dom, agressão, conquista e esperança de consumação do outro; interioridade manifesta, livre da necessidade de invadir fisicamente o objeto de seu desejo; o som vocalizado vai de interior a interior e liga, sem outra mediação, duas existências. (ZUMTHOR, 2010, p. 13).

Tais proposições de Zumthor (2010) são bastante significativas para esta pesquisa, uma vez que também ele, assim como Cavarero (2011), destaca o fato de que a voz revela, "informa sobre a pessoa, por meio do corpo que a produziu", buscando, com isso, seduzir o outro (no caso, o/a ouvinte), pois ela, a voz, segundo o autor, é "esperança de consumação do outro".

Assim, considero necessário pensar em "voz", tanto no sentido mais corrente, relacionado aos que executam uma canção, como também em um sentido metafórico, como indicação de uma visão específica de canção, arte, referências, tradições e ressonâncias.

Além disso, outro aspecto importante relacionado à voz, em seu sentido literal - som que emana do corpo (ZUMTHOR, 2014) -, está na dificuldade de descrevê-la e, portanto, de analisá-la como objeto de estudo (ou parte dele) no meio acadêmico. Segundo Ruth Finnegan (2008),

a voz é mais que mero condutor de textualidades preexistentes, sejam verbais ou musicais. De um modo frequentemente negligenciado em relatos acadêmicos [...], a voz é, ela mesma, em sua presença melódica, rítmica e modulada, parte da substância. Pois a "letra" de uma canção em certo sentido não existe a menos e até que seja pronunciada, cantada, trazida à tona com os devidos ritmos, entonações, timbres, pausas; tampouco a canção tem "música" até que soe na voz. Aqui, canção e poesia oral significam a ativação corporificada da voz humana - fala, canto, entoação, em solo, em coro, harmonizada, a cappella, amplificada, distorcida, mutuamente afetada por diferentes formas de instrumentação, ao vivo, gravada -, todo um arsenal de variadas apresentações para o ouvido humano (FINNEGAN, 2008, p. 24, grifos no original).

Tratar a voz (ou as vozes) como elemento essencial na análise de canções, em suas 
performances, apesar das dificuldades que isso implica, é um dos objetivos deste trabalho, pois uma das estratégias mais utilizadas por Itamar Assumpção, na tentativa de sedução de seu público ouvinte, está justamente na presença constante de múltiplas vozes em suas canções, seja pela presença de cantoras inventivas e talentosas, como Tetê Espíndola, Ná Ozzetti, Mirian Maria, entre outras, que participavam das gravações de vários de seus discos; seja pela experimentação que Itamar realizava, ao brincar com sua própria voz, não raro, deslizando do canto para a fala, apagando as barreiras entre ambos e evocando a oralidade das conversas cotidianas.

Essa multiplicidade explorada por Itamar Assumpção em suas composições encontra ressonância no universo plural da canção brasileira - gênero por natureza híbrido, que mescla linguagens da música popular e da literatura, e no qual coexistem diferentes gêneros musicais, como o samba, o forró, o reggae, e o rock, por exemplo.

Sobre esse aspecto na obra de Itamar, escreveu o também músico e compositor - além de professor e pesquisador - Luiz Tatit, em um ensaio chamado "A transmutação do artista", de 2014, no qual ele analisa boa parte da trajetória musical do compositor. Segundo Tatit (2014), Itamar Assumpção

sempre precisou dizer (ou cantar) diversas frases ao mesmo tempo, inserir numa simples cantiga numerosos acontecimentos musicais e, mesmo assim, sua obra só se completava no disco integral, pleno de retomadas, vinhetas e comentários de toda espécie. (TATIT, 2014, p. 311).

Essa forma peculiar de compor pode ser percebida já em seu primeiro disco, em que as canções incorporam não só referências a outras canções, mas também outros gêneros do universo sonoro como vinhetas e locuções radiofônicas (quando é feita a apresentação dos músicos, por exemplo), quanto no momento da execução de algumas canções, como no caso de "Luzia", em que as vocalistas assumem papel decisivo na interpretação, dando voz (ou vozes) à mulher do personagem que dá nome ao disco ${ }^{4}$.

No entanto, é certamente a partir de seu terceiro álbum, Sampa midnight - isso não vai ficar assim $^{5}$, que Itamar começa a abrir terreno para que outras vozes possam assumir a enunciação do discurso - e não mais apenas aquela do marginalizado, que guiou os primeiros álbuns do compositor. Entretanto, a voz do marginalizado nunca sai de cena.

\section{Composição e recepção: o prezadíssimo ouvinte}

A pluralidade inventiva e desconcertante da obra de Itamar Assumpção se verifica em diversos níveis e estratégias, como vimos no item anterior deste artigo. O seu público também é incorporado em suas canções, nas quais, muitas vezes, há um diálogo direto com um/a ouvinte.

\footnotetext{
${ }^{4}$ A marginalidade de Nego Dito fica clara, inclusive nas violências que comete contra Luzia, representada pelas múltiplas vozes das cantoras, como se o disco, desse modo, falasse das muitas mulheres vítimas de parceiros violentos em seu cotidiano, num país em que ainda vigoram altos índices de violência contra a mulher.

${ }^{5}$ Originalmente gravado pelo selo independente Mifune Produções, em 1985.
} 
Isso ocorre, por exemplo, em "Prezadíssimos ouvintes", canção que abre o disco Sampa Midnight, composta em parceria com Domingos Pellegrini ${ }^{6}$, na qual Itamar promove um diálogo mais íntimo com seu ouvinte, estabelecendo, assim, uma dinâmica de reciprocidade. $\mathrm{O}$ ouvinte é tratado inicialmente com respeito e esmero, conforme indica o título da canção, em que a forma "prezados" é usada em seu superlativo absoluto sintético, "prezadíssimos", ou seja, no máximo grau do qualificativo, o que, por ter efeito hiperbólico, pode ser lido ainda como um operador de ironia, o que é muito comum nesses casos. Uma hipótese cabível é que esses ouvintes qualificados como "prezadíssimos", imaginários, desconhecidos, possam retribuir a atenção dada pelo músico, estando, no mínimo, com os "ouvidos atentos" e dispostos a participar efetivamente do diálogo.

A respeito dessa expectativa de recepção por parte de um ouvinte imaginário, retomo as pesquisas sobre poéticas orais, e sobre "performance e recepção", do teórico suíço Paul Zumthor, um dos estudiosos mais representativos do tema. Seus estudos contemplam tanto os textos mais tradicionais da "voz viva", desde a Idade Média, passando por diversas épocas e regiões, quanto os que são circulados por meio de suportes mais diversificados e contemporâneos, como os da cultura de massa. Zumthor (2010), em seu livro Introdução à poesia oral, comenta, inclusive, sobre a canção e seu receptor. Vejamos:

Guiada por um sujeito desconhecido, imprevisível, uma escuta vazia, a canção, por isso mesmo, espera o receptor real, desejado, futuro virtual do cantor, seu Outro. Entretanto, ao longo da história, as culturas que o homem inventou para si mesmo integraram, de modo desigual, os valores poéticos da voz. (ZUMTHOR, 2010, p. 181).

A expectativa de um "receptor real" - alguém que, ao ouvir tal canção, pudesse, em seguida, se apropriar dela e cantá-la como sendo de sua autoria - tem presença marcante na obra de Itamar, desde o álbum Sampa Midnight (1985), já que, conforme mencionado, é, sobretudo, a partir desse disco que o compositor passa a explorar outras vozes, outros discursos. Coincidentemente ou não, é a partir daí que suas canções passam a ser regravadas por outros intérpretes com maior frequência, tais como Ney Matogrosso, Cássia Eller e Zélia Duncan. É importante também atentar para a centralidade concedida pelo compositor/cantor à recepção, uma vez que os receptores são referidos logo no início do disco, o que evidencia o trabalho conjunto de construção dos sentidos em uma obra de arte, seja ela qual for, na medida em que solicita a participação ativa de um/a receptor/a situado/a em um contexto específico, mas que deve estar aberto/a ao que a obra propõe como experiência. Sua obra é como um convite a uma recepção atenta e criativa, como num diálogo em que o receptor não apenas recebe passivamente a mensagem, mas reage a ela com novos impulsos.

A participação desse "público prezadíssimo" exige capacidade de deslocamento e reflexão, quase sempre, na audição de suas canções, em que primeiro é questionado um modo de ouvir ou um modo de compor/cantar, mais responsivo. Nesse disco, em especial, a voz do

\footnotetext{
${ }^{6}$ Domingos Pellegrini Jr. (Londrina, 1949) é romancista, contista, cronista, poeta, jornalista e publicitário.

${ }^{7}$ Expressão usada por Itamar na abertura de seu primeiro disco, Beleléu, leléu, eu, de 1981.
} 
personagem marginalizado, que denuncia a vida quase excludente daqueles que não se curvam às padronizações estéticas impostas, no caso, pela indústria fonográfica, se faz presente e convida o/a ouvinte a acompanhá-lo nesse percurso, abandonando o "centro" e seguindo pelas margens, num percurso "ex-cêntrico". E é essa voz que abre o disco.

Em "Prezadíssimos ouvintes", ainda, Itamar se apropria de um poema de Paulo Leminski (2013) - poeta paranaense que compartilhou com ele diversas parcerias - para apresentar-se ao público, a seu prezado ouvinte, entoando os seguintes versos (semelhante às vinhetas de programas de rádio):

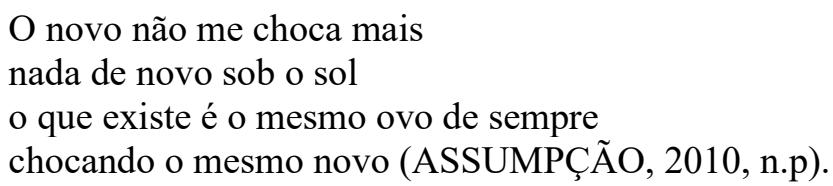

Aqui, é válido destacar um recurso composicional frequente em muitas outras composições. Nesta, o músico apropria-se de um outro texto - neste caso, um poema de Paulo Leminski - e o incorpora ao seu, à sua composição, formando assim um todo (quase) homogêneo. Proposta, inclusive, muito semelhante à "antropofagia cultural", pensada e exercida no início do século passado pelo poeta paulista Oswald de Andrade - certamente o modernista que mais procurou reinventar a poesia brasileira da época, tanto em seus aspectos técnicos quanto culturais. Dos legados deixados pela antropofagia oswaldiana, o que mais nos interessa de perto é a ideia de "apropriação". Esta, voltando à análise, fica ainda mais clara quando, no encarte do já referido disco, se percebe que não há referência à citação do poema ${ }^{8}$. Além disso, comparando-o com o poema original ${ }^{9}$, percebe-se que alguns versos foram ligeiramente modificados. Itamar não só se apropria, como também subverte o poema de Leminski, dando claros sinais de que sua memória cultural será referência importante em muitas de suas composições, afinal a memória “[...] é um elemento essencial do que se costuma chamar identidade, individual ou coletiva, cuja busca é uma das atividades fundamentais dos indivíduos e das sociedades de hoje." (LE GOFF, 2013, p. 435, grifo no original).

A construção dessa identidade, pensada aqui, segundo Stuart Hall (2003, p. 106), "[...] como uma construção, como um processo nunca completado, como algo sempre em 'processo'[...]", se faz múltipla e em contínua transformação, pois, de acordo com Octavio Paz (2013, p. 37), "não somos regidos pelo princípio de identidade e suas enormes e monótonas tautologias, e sim pela alteridade e pela contradição." Por isso é realizada, na produção de Itamar, a partir da apropriação de diversas outras vozes, que ele incorpora à sua própria e que reivindica como sua, na medida em que as memórias são transmutadas em novas composições, abertas a outros diálogos e transpostas, no caso do poema de Leminski, das páginas do livro impresso para o universo sonoro do disco. Essa apropriação reforça a centralidade da voz na

\footnotetext{
${ }^{8}$ É importante ressaltar que, neste caso, o disco foi lançado originalmente em 1985, e sem encarte. Apenas dois anos depois, o encarte passou a fazer parte do disco.

9 "O novo / não me choca mais / nada de novo / sob o sol / apenas o mesmo / ovo de sempre / choca o mesmo novo." (LEMINSKI, 2013, p. 56).
} 
circulação do poema, que teve, como nos ensina Zumthor $(2010 ; 2014)$, durante muitos e muitos séculos, o corpo como mídia privilegiada para a sua circulação, sustentada pela voz dos/as que compuseram o poema e/ou o guardaram em suas memórias para partilhá-lo com outras vozes, para inscrevê-lo em outras memórias, conforme podemos observar na letra da canção transcrita abaixo:

O novo não me choca mais

Nada de novo sob o sol

O que existe é o mesmo ovo de sempre

Chocando o mesmo novo

Muito prazer

Prezadíssimos ouvintes

Pra chegar até aqui

Eu tive que ficar na fila

Aguentar tranco na esquina

E por cima lotação

Noite, e aqui tô eu novo de novo

Com vinte e quatro costelas

O gogó, baixo, guitarra

Ligadas numas tomadas elétricas e pulmão

Já cantei num galinheiro

Cantei numa procissão

Cantei ponto de terreiro

Agora eu quero cantar na televisão

Meu irmão, o negócio é o seguinte

É pura briga de foice

Um jogo de empurra-empurra

Facão, tiro, chute, murro

Chamam mãe de palavrão

Sorte não haver o que segure

Som senhoras e senhores

Mas quem é que me garante

Que mesmo esses microfones

Sempre funcionarão?

Cantei tal qual seresteiro

Cantei paixão, solidão

Cantei canto de guerreiro

Agora eu quero cantar na televisão (ASSUMPÇÃO, 2010, n.p).

A referência ao poema de Leminski, no início da canção, na abertura do disco, é, no mínimo, emblemática. Como destaquei acima, essa estratégia dá outra voz aos versos que originalmente foram publicados em livro. Isso acaba confirmando aquilo que Zumthor (2010) já havia mencionado: 
Dita, a linguagem submete-se à voz; cantada, ela exalta sua potência, mas, por isso mesmo, glorifica a palavra... mesmo ao preço de algum obscurecimento do sentido, de uma certa opacificação do discurso: exalta menos como linguagem que como afirmação de potência. (ZUMTHOR, 2010, p. 199, grifos meus).

Entretanto, essa "afirmação de potência" da linguagem quando cantada, de que fala Zumthor (2010), não pode ser, neste caso, entendida literalmente em sua amplitude, já que os referidos versos de Leminski foram, na verdade, ditos, falados, e não necessariamente cantados. No entanto, ao trazê-los para a abertura da canção (e do disco), Itamar, também de forma subjetiva, "glorifica a palavra", os versos, dando-lhes outra voz - a sua voz, que tanto aproxima o canto da fala, e vice-versa.

Além disso, o fato de terem sido convocados para o início do seu mais novo álbum justamente o que considero ser um divisor de águas na produção musical de Itamar —, acaba justificando a escolha do poema leminskiano, cujo tema aborda a ideia de que não existe nada de realmente "novo" em termos de arte. Ou, se existe, tal "novidade" não parecia provocar interesse em Itamar, já que, de acordo com a visão de Jacques Le Goff (2013), o termo "novo" "implica nascimento, um começo que, com o cristianismo, assume o caráter quase sagrado de batismo [...] Mais do que uma ruptura com o passado, 'novo' significa um esquecimento, uma ausência de passado" (LE GOFF, 2013, p. 166).

Assim, indo ao encontro dessa fala de Le Goff (2013), e ao contrário do que muitas vezes é colocado, Octavio Paz (2013) nos diz que "o novo não é exatamente o moderno, a menos que seja portador da dupla carga explosiva: ser negação do passado e ser afirmação de algo diferente." (PAZ, 2013, p. 17).

E Itamar não nega o passado, pois, ao cantarolar os versos, à sua maneira, com vozes sobrepostas às outras, entoando os versos, e tomando-os como seus, potencializa uma voz que já vinha desde seu primeiro disco, e, através dela, alerta os seus "prezadíssimos" ouvintes para o fato de que ele, Itamar, não pretende ceder às armadilhas do meio fonográfico, o qual está sempre à procura daquilo que é considerado "novo" e atraente para o mercado, desmitificando, assim, a noção de novo - um dos recursos do mercado, já que a novidade é uma das justificativas do consumo.

$\mathrm{Na}$ letra da canção propriamente dita, há uma narrativa que evidencia a trajetória árdua de um compositor popular que, "pra chegar até aqui", até o reconhecimento do público e da crítica (ou mesmo até o disco, cuja feitura era muito mais dispendiosa naquele período, com gastos altos e proibitivos para muitos/as), e ao momento de sua maturidade artística, precisou, antes disso, "ficar na fila / aguentar tranco na esquina...", cantar na noite, brigar num "jogo de empurra-empurra", alimentando, ainda, as dúvidas e incertezas sobre seu futuro na música:

Mas quem é que me garante

Que mesmo esses microfones

Sempre funcionarão? (ASSUMPÇÃO, 2010, n.p).

$\mathrm{Na}$ execução da canção, Itamar repete o primeiro verso dessa estrofe, assumindo, assim,

Anu. Lit., Florianópolis, v. 25, n. 2, p. 86-100, 2020. ISSNe 2175-7917 
uma postura em que a dúvida é articuladora dos sentidos, mesmo quando se trata da relação, aparentemente objetiva, entre o corpo do artista e os objetos que potencializam a sua voz. Além disso, "incerteza" é uma palavra que se liga ao campo semântico de pluralidade, de transmutação, pois, o prefixo de negação "in" aponta para a ideia de que não há, digamos, um caminho "certo", único, e que deva ser seguido sem quaisquer problematizações ou dúvidas.

E mesmo com essas incertezas, há, contraditoriamente, a convicção de que sua voz é potencializada no canto, independente do funcionamento dos meios eletrônicos que lhe dão amplitude, como os microfones. Afinal, sua música, além de contar com baixos e guitarras, ligados "numas tomadas elétricas", conta também com o que lhe é de fato essencial: gogó e pulmão, ou seja, a voz natural.

Nesse sentido, considero relevante a percepção de Luiz Tatit (2014) acerca da atuação da voz (ou do 'eu') em um texto oral, quando afirma:

Claro que não preciso dizer "eu" literalmente para me fazer sentir como enunciador do texto. Quando digo "você", "tu”, “o senhor" ou qualquer outro indício de que me dirijo a alguém (imperativos, demonstrativos, nomes próprios etc.), imediatamente me instalo como "eu", já que ninguém pode se dirigir ao outro sem estar presente. E quando o texto é oral (ou cancional), conduzido por entoações (ou melodias), essa presença [do 'eu'] torna-se física, se não pela participação do corpo do enunciador (como num show), no mínimo pela atuação da voz (como num disco). (TATIT, 2014, p. 312).

Quando essa atuação da voz se dá, por exemplo, em um disco gravado em estúdio, é importante atentar para outros aspectos além do registro auditivo. O projeto gráfico de um disco, normalmente, conta também com um encarte, onde, entre outras coisas, estão impressas as letras das canções. Observando o encarte de Sampa Midnight ${ }^{10}$, pude constatar que aquilo que se ouve nem sempre está registrado na letra. Esse tipo de procedimento, inclusive, é recorrente em Itamar Assumpção - o que confirma a hipótese de que sua obra, conforme assinala Tatit (2014, p. 311), "só se completava no disco integral, pleno de retomadas, vinhetas e comentários de toda espécie.”.

No caso específico da canção "Prezadíssimos ouvintes", além de comentários e sons aparentemente desconexos, soltos, versos inteiros são acrescidos à letra, mas que só são percebidos quando a ouvimos, pois não estão previstos no encarte. Por isso, talvez o termo "prezadíssimos" se referindo aos ouvintes, ou a expressão "ouvidos atentos", na abertura de seu primeiro disco. Itamar exigia de seus ouvintes um outro modo de audição, mais responsivo, como num diálogo, numa perspectiva bakhtiniana (2011). Sua poética excedia o espaço-limite que lhe era destinado. Afinal,

a poesia aspira, como a um propósito ideal, a se depurar das limitações semânticas, a sair da linguagem, ao alcance de uma plenitude, onde tudo que não seja simples presença será abolido. A escrita reprime ou esconde essa aspiração. A poesia oral, ao contrário, acolhe seus fantasmas e tenta lhes dar

${ }^{10}$ Encarte fac-símile relançado no Box Caixa Preta, pelo Sesc São Paulo, em 2010. 
forma [...] (ZUMTHOR, 2010, p. 179).

E dentre essas outras vozes complementares, estão os versos de "Sentimental demais", composição de Jair Amorim e Evaldo Gouveia, e eternizada na voz de Altemar Dutra, mas que aqui são interpretadas por Itamar, em uma segunda voz, ao fundo e paralela à voz principal, a qual interpreta a letra da música. E mais uma vez não há referência textual sobre a citação no encarte do disco, tampouco na letra da canção. São versos que surgem provavelmente da memória musical e afetiva de Itamar Assumpção, do compositor como um ouvinte inserido numa tradição musical complexa e diversa, e emergem, no momento da gravação, inscrevendose na tessitura do que é cantado. Desse diálogo, entre o Itamar compositor e o ouvinte, surgem para nós, como citação, os versos de "Sentimental demais", os quais, por meio de procedimentos paratáticos, complementam semanticamente os demais versos da canção, abrindo outros planos de significação e relação.

Neste caso, os versos de Jair Amorim e Evaldo Gouveia aparecem na canção de Itamar no segundo refrão, os quais destaco a seguir entre parênteses, numa tentativa de aproximar o momento exato em que as vozes do primeiro e segundo planos são ouvidas:

Cantei tal qual seresteiro (sentimental eu sou)

Cantei paixão, solidão (eu sou demais)

Cantei canto de guerreiro (eu sei que sou assim / porque assim ela me faz)

Agora eu quero cantar na televisão (AMORIN; GOUVEIA, 1965, n.p).

Logo após cantar o verso "cantei tal qual seresteiro", Itamar Assumpção justifica a comparação buscando, em sua memória, uma referência forte que a palavra "seresteiro" pudesse evocar. E, neste caso, sua memória nos trouxe a canção dos compositores seresteiros Jair Amorim e Evaldo Gouveia, a qual ficou ainda mais conhecida na voz imponente de Altemar Dutra, conforme já mencionei. Assim, ao utilizar a forma verbal "cantei”, no pretérito perfeito, indicando, portanto, uma ação já concluída, e, em seguida, promovendo uma comparação com o modo de cantar dos seresteiros - comumente marcado por vozes eloquentes e temas tipicamente românticos, como o sentimentalismo exagerado -, era natural que Itamar mais uma vez se apropriasse de versos de alguma outra canção para, com isso, estabelecer um diálogo no qual os discursos se complementam.

Ao ouvir Itamar, somos sempre convidados a recompor esse mosaico que ele articula, e que, muitas vezes, é apenas referido metonimicamente (por um ou mais versos da canção evocada). Assim, a memória que o compositor mobiliza e retoma é, simultaneamente, individual e coletiva. Individual porque nos revela um outro lugar do compositor: o de ouvinte/leitor; de alguém que, como muitos de nós, foi complementando a sua bagagem cultural ao longo dos anos, a partir de suas experiências, sobretudo, enquanto ouvinte que certamente aprecia uma audição mais responsiva, capaz de ampliar as possibilidades de diálogo entre os textos. É também coletiva, como reflexo de uma herança cultural construída, neste caso, em uma tradição específica: a tradição musical brasileira. A partir dela, de sua memória, somos também tentados a exercitar, ainda que involuntariamente, a nossa própria, dentro dessa mesma 
tradição.

Assim, os versos de "Sentimental demais" escolhidos por Itamar e cantados por ele funcionam, num primeiro plano, como uma resposta para os seus próprios versos, estabelecendo um breve diálogo textual entre as vozes, e entre os discursos. Ao afirmar, por exemplo, que cantou temas como "paixão" e "solidão", Itamar também se assume sentimental, romântico, seresteiro ("cantei paixão, solidão - eu sou [sentimental] demais"). No entanto, num segundo plano, a melodia conhecida dos versos cantados por Itamar nos faz, enquanto ouvintes situados numa mesma tradição, navegar nos lagos esquecidos de nossa memória, e, a partir daí, também nos faz desenvolver algum tipo de diálogo entre as canções. Somos, pois, convocados a participar efetivamente da canção, como ouvintes atentos.

Assim, ao retomar a famosa e tradicional canção do cancioneiro popular brasileiro, Itamar não só a homenageia, enquanto eco de sua memória seletiva, mas também a lança para novos enunciados e públicos, estabelecendo, desse modo, uma nova rede de discursos entre os seus "prezadíssimos ouvintes". Vejamos a letra completa:

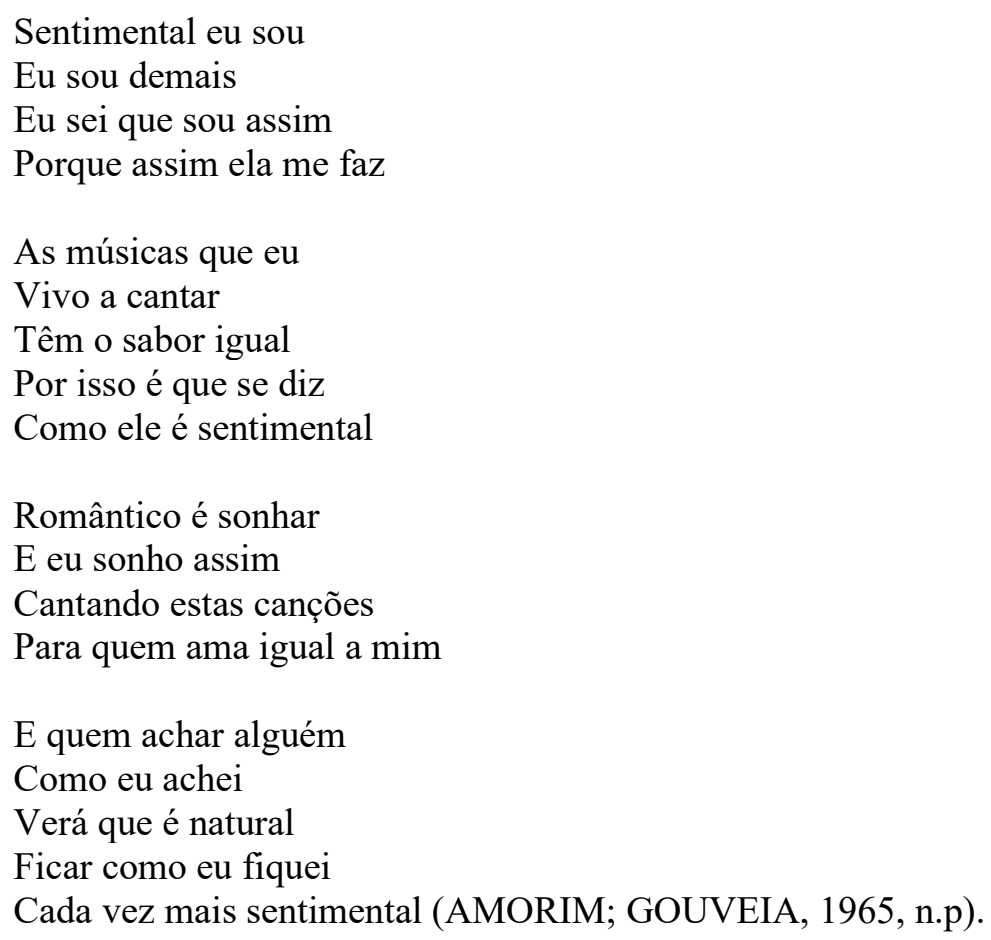

É importante destacar que os outros versos de "Sentimental demais", os que não foram interpretados por Itamar em sua composição, também podem nos oferecer ainda mais elementos para que possamos entender a dimensão do diálogo entre essas canções. Como se pode notar a partir das transcrições, Itamar Assumpção canta apenas a primeira estrofe e silencia as demais. Som e silêncio, evocação explícita e evocação parcial ou metonímica, movimentos da voz e da memória. No entanto, os versos não cantados não foram de todo silenciados. Afinal, em casos assim, me parece ser comum que o ouvinte, já de certa forma familiarizado com as estratégias utilizadas pelo compositor, e com a melodia conhecida daqueles versos iniciais, busque também em sua própria memória os demais versos e passe a cantarolar, ainda que em silêncio, toda a 
canção.

\section{Agora eu quero cantar na televisão: uma conclusão}

No último verso de "Prezadíssimos ouvintes" há uma presentificação do discurso - do pretérito perfeito para o presente do indicativo: "agora eu quero cantar na televisão" (ASSUMPÇÃO, 2010, grifo meu). E é certamente esse verso o guia de toda a trajetória narrada na letra da música. Das dificuldades do início de carreira à aceitação do público e da crítica, Itamar chega à conclusão de que quer "cantar na televisão". Entretanto, desde que não fosse preciso abrir concessões ou ceder a padronizações estéticas, o músico parecia querer cada vez mais transfigurar-se em outras vozes; em outras personas, conforme aponta Luiz Tatit (2014):

\footnotetext{
Itamar trouxe de sua vivência teatral de juventude um personagem que sempre o acompanhou nas apresentações musicais, como uma espécie de "eu" absoluto cuja história só poderia ser desvendada pelas canções. A cada show e a cada novo disco, os ouvintes conheciam um pouco mais desse mundo subjetivo, porém, davam-se conta de que este "eu" transformava-se em outros e tornava-se inesgotável. (TATIT, 2014, p. 312-313).
}

Na canção aqui analisada, "Prezadíssimos ouvintes", é possível perceber, portanto, um elo entre a fase inicial de Itamar - guiada pela voz de um personagem marginalizado, mas que já utilizava inventivos recursos estilísticos de composição, que serão revisitados nos próximos álbuns - e suas composições seguintes, permeadas por diversas vozes, tanto de sua memória cultural, quanto possíveis ecos de sua permanente transmutação enquanto artista.

Sobre isso, Luiz Chagas, músico que o acompanhou em boa parte de sua jornada, explica que "as canções de Itamar soam complicadas porque vêm em camadas. Suas bandas, notadamente a Isca de Polícia e Orquídeas do Brasil, têm por volta de oito elementos que tocam e trocam informações o tempo todo" (CHAGAS, 2006, p. 12).

A formação de bandas com muitos músicos e cantores reforça a noção de pluralidade, que perpassa a poética de Itamar, pois cada um desses elementos "tocam e trocam informações o tempo todo", não permitindo que aqueles que conviveram de perto com Itamar, segundo a musicista Clara Bastos (2006), passassem em branco, sem deixar a sua marca. Isso porque, segundo a baixista e uma das integrantes das Orquídeas do Brasil,

sua música não permitia um envolvimento superficial dos músicos. Compartilhava conversas e refeições. Não era possível fazer "mais ou menos" parte. Isso gerava conflitos em alguns casos. Resolvidos ou não, esses conflitos mostravam ao menos a presença de vitalidade nas relações entre as pessoas, o que refletia beneficamente no resultado final: gravação ou show. (BASTOS, 2006, p. 82).

Daí a singularidade das composições de Itamar. As canções nunca eram executadas da mesma maneira nas apresentações ao vivo (ou em regravações), já que cada instrumentista (incluindo as backing vocals) contribuía para a performance (no palco ou no estúdio) com alguma informação sua, pois havia, entre eles, uma abertura representativa por onde circulavam 
as trocas.

O corpo e a voz ganham, na poética de Itamar Assumpção, proporções bastante consideráveis do ponto de vista composicional, quase sempre da (des)ordem do inusitado, do desconcertante, afinal "o novo é novo se for inesperado." (PAZ, 2013, p. 16). Assim, os/as prezadíssimos/as ouvintes que chegavam até o fim dos seus discos provocativos eram convidados/as a reorganizar sua memória, a reconhecer as múltiplas vozes que os/as constituem e desafiam continuamente.

\section{Referências}

AMORIM, Jair; GOUVEIA, Evaldo. Sentimental demais. Intérprete: Altemar Dutra. In: DUTRA, Altemar. Sentimental demais. [São Paulo]: Odeon, 1965. 1 CD. Faixa 1.

ASSUMPÇÃO, Itamar. Beleléu, leléu, eu. São Paulo: Baratos Afins, 1989. 1 LP.

ASSUMPÇÃO, Itamar. Sampa Midnight - Isso não vai ficar assim. Box Caixa Preta. São Paulo: Selo Sesc, 2010.

BAKHTIN, Mikhail. Estética da criação verbal. Trad. de Paulo Bezerra. 6. ed. São Paulo: Martins Fontes, 2011.

BASTOS, Clara. Livro de canções. In: CHAGAS, Luiz; TARANTINO, Mônica (Orgs.). PretoBrás: por que que eu não pensei nisso antes? O livro de canções e histórias de Itamar Assumpção. São Paulo: Ediouro, 2006, p. 79-85. v. 1.

CAVARERO, Adriana. Vozes plurais: filosofia da expressão vocal. Trad. de Flavio Terrigno Barbeitas. Belo Horizonte: Editora UFMG, 2011. (Coleção Humanitas).

CHAGAS, Luiz. Apresentação: Ouvidos atentos. In: CHAGAS, Luiz; TARANTINO, Mônica (Orgs.). PretoBrás: por que que eu não pensei nisso antes? O livro de canções e histórias de Itamar Assumpção. São Paulo: Ediouro, 2006, p. 12. v. 1.

CHAGAS, Luiz; TARANTINO, Mônica (Orgs.). PretoBrás: por que que eu não pensei nisso antes? O livro de canções e histórias de Itamar Assumpção. São Paulo: Ediouro, 2006. 2 v.

FINNEGAN, Ruth. O que vem primeiro: o texto, a música ou a performance? Trad. de Fernanda Teixeira de Medeiros. In: MATOS, Cláudia Neiva de; TRAVASSOS, Elizabeth; MEDEIROS, Fernanda Teixeira de (Orgs.). Palavra cantada: ensaios sobre poesia, música e voz. Rio de Janeiro: 7Letras, 2008, p. 15-43.

HALL, Stuart. Quem precisa da identidade?. In: SILVA, Tomaz Tadeu da (Org.). Identidade e diferença: a perspectiva dos estudos culturais. Petrópolis: Vozes, 2003, p 103-133.

LE GOFF, Jacques. História e Memória. Trad. de Bernardo Leitão, Irene Ferreira e Suzana Ferreira Borges. 7. ed. rev. Campinas: Editora Unicamp, 2013.

LEMINSKI, Paulo. Toda poesia. São Paulo: Companhia das Letras, 2013.

PAZ, Octavio. Os filhos do barro: do romantismo à vanguarda. Trad. de Ari Roitman e Paulina Wacht. São Paulo: Cosac Naify, 2013. 
TATIT, Luiz. O cancionista: composição de canções no Brasil. 2. ed. São Paulo: Editora da Universidade de São Paulo, 2002.

TATIT, Luiz. Todos entoam: ensaios, conversas e lembranças. 2. ed. rev. amp. Cotia: Ateliê Editorial, 2014.

ZUMTHOR, Paul. Introdução à poesia oral. Trad. de Jerusa Pires Ferreira, Maria Lúcia Diniz Pochat e Maria Inês de Almeida. Belo Horizonte: Editora UFMG, 2010. (Coleção Humanitas).

ZUMTHOR, Paul. Performance, recepção, leitura. Trad. de Jerusa Pires Ferreira e Suely Fenerich. São Paulo: Cosac Naify, 2014. (Coleção Portátil; v. 27).

\section{NOTAS DE AUTORIA}

Bruno César Ribeiro Barbosa (brunoribeiro.barbosa@gmail.com) é doutor em Estudos Literários pela UFAL (2019); licenciado em Letras - habilitação: Português / Literatura pela mesma instituição (2005). É professor efetivo do Instituto Federal de Educação, Ciência e Tecnologia de Alagoas (IFAL), campus Marechal Deodoro. Possui experiência nas áreas de Letras e de Comunicação, ênfase em Literatura Brasileira, atuando principalmente nos temas: poesia brasileira contemporânea, canção popular, invenção, circulação e extensões poéticas.

\section{Como citar esse artigo de acordo com as normas da revista}

BARBOSA, Bruno César Ribeiro. Ouvidos atentos: as vozes plurais de Itamar Assumpção. Anuário de Literatura, Florianópolis, v. 25, n. 2, p. 86-100, 2020.

\section{Contribuição de autoria}

Não se aplica.

\section{Financiamento}

Não se aplica.

\section{Consentimento de uso de imagem}

Não se aplica.

\section{Aprovação de comitê de ética em pesquisa}

Não se aplica.

\section{Licença de uso}

Este artigo está licenciado sob a Licença Creative Commons CC-BY. Com essa licença você pode compartilhar, adaptar, criar para qualquer fim, desde que atribua a autoria da obra.

\section{Histórico}

Recebido em: 30/05/2020

Revisões requeridas em: 21/08/2020

Aprovado em: 29/08/2020

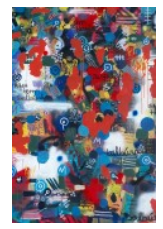

